\title{
The Localization of the Indigo-producing Substance in Indigo-yielding Plants.
}

BY

\author{
H. M. LEAKE, M.A., F.L.S.
}

With Plate XIII.

THAT there is present in numerous plants scattered through the 1 vegetable kingdom a body which, under certain conditions, is capable of yielding indigo has been a matter of general knowledge from very remote ages. This knowledge, however, was chiefly acquired as the result of the utilitarian purposes to which indigo is put; thus the woad, Isatis tinctoria, L., was largely cultivated in Europe until the dye so obtained was replaced by indigo imported from the East; Polygonum tinctorium, Ait., was, and is still, cultivated in China ; Indigofera argentea, L., is the ancient 'nil' known to, and cultivated by, the Egyptians ; and there are cultivated, chiefly in India and Java, other species of Indigofera too numerous to be mentioned individually.

\section{LITERATURE.}

Schunck in 1855 (1) attempted to obtain some knowledge of the body which existed in the woad and from which indigo could be obtained. To this body he gave the name 'Indican.'

During the last twelve years a considerable amount of work has been published, the greater portion of which comes from the pens of Molisch and Beijerinck. These two investigators, however, are chiefly concerned with the industrial processes and questions concerning the fermentative and bacterial action.

Of work dealing more particularly with the localization of the indigoforming substance within the plant there is comparatively little. The earliest suggestion of a method for indicating the situation of this substance within the plant occurs in the Botanische Zeitung for 187 I (3). Here Göppert, in dealing with the effect of frost on plants, notes that, when a flower of Phajus grandifolius, Lour., is killed by frost, part of the flower becomes blue. The fact is, however, only noted incidentally, and no effort is made to localize the indigo-forming substance. Attention is again drawn by Müller-Thurgau (4) to this precipitation of indigo in the flower of Phajus grandifolius, when it is killed by freezing.

[Annals of Botany, Vo1. XIX. No. LXXIV. April, 1905.] 
The first experiments to be undertaken with the definite object of localizing the indigo-forming substance within the tissues of the plant are those of Molisch, published in 1893 ( 5 and 6 ). In these experiments he uses two methods for ascertaining whether a particular tissue contains this substance. The first, or macro-chemical, method consists in boiling the tissue with dilute ammonia ( 2 c.c. commercial in 98 c.c. water); indigo is thus formed and will become evident on filtering, when the masking colour of the filtrate is removed. Chloroform may be added to the unfiltered ammoniacal extract, when the chloroform will separate out as a blue layer, for indigo is slightly soluble in chloroform. In the second, or micro-chemical, method the tissue is exposed in a confined atmosphere to the action of alcohol vapour for a period of twenty-four hours, after which the chlorophyll may be removed by immersion in absolute alcohol. The presence of indigo, and hence of the indigo-forming substance, will be indicated by the blue coloration of the tissue. In a later paper in 1899 (7) he suggests chloroform as an alternative for alcohol, and later again, in the same year (8), strong ammonia. Direct immersion in $40 \%$ alcohol also results in a formation of blue within the tissues. Sections can now be cut, or the material teased and examined under the microscope.

Beijerinck, in 1899 (9), in applying the 'alcohol test' of Molisch to Indigofera arrecta, Hochst. (termed by him $I$. leptostachya), found that indigo-formation occurred in only the youngest leaves. In the 'woad,' again, only a slight blue deposition occurs. As an alternative and more satisfactory method, he immersed the tissue used for experiment in mercury, or exposed it in a vacuum, for a few hours, after which he exposed to ammonia vapour as before, finally extracting the chlorophyll with alcohol.

In I900 (10) he uses as a macro-chemical method the addition of hydrochloric acid and ferric chloride to a decoction of the tissue to be examined, and adapts this reaction for micro-chemical examination by boiling a section of the living leaf or tissue in a mixture of strong hydrochloric acid and ferric chloride. As an alternative he uses in the same manner a solution of isatin in hydrochloric acid, by which reagent the indigoforming substance is supposed to yield indigo-red, which is deposited in situ within the tissue. The former method of indicating the presence of an indigo-forming substance by the formation of indigo as the result of the action of an acid and ferric chloride is also used by Hazewinkel (11).

\section{Methods.}

The above methods are in no case of such a character as to give to the tissue a condition at all comparable to that of material treated by the ordinary fixing and hardening reagents, and the microscopic examination 
must consequently be somewhat imperfect; moreover, with the exception of one plate (Ber. der D. B. Gesell., Bd. xviii, I899, Taf. I8), in which the distribution in the cells of Isatis and Calanthe, as indicated by the deposition of blue induced by exposure to alcohol vapour, is figured, the results are not illustrated. It seemed, therefore, that if a suitable method could be obtained for precipitating the indigo within the cells of the tissue and at the same time producing all the results of a fixing reagent, thus leaving the material in a suitable condition for hardening and staining in the ordinary manner, there would be room for further examination. This especially applies to examples of the genus Indigofera. By far the greater portion of the previous work has been carried out in Europe, and hence this genus, which is chiefly tropical in its habit, has received comparatively little attention. Such a method was eventually found and will be briefly described. The tissue to be examined is cut into small pieces and rapidly immersed in a solution of the following constitution:-

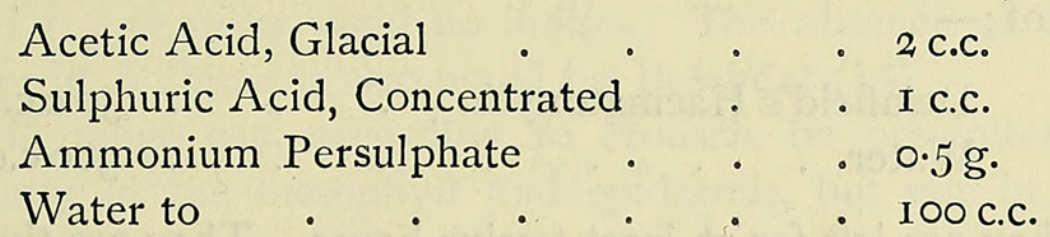

In compact tissues, such as those of Indigofera, where the intercellular spaces are small, penetration is slow and the pieces must be relatively small $-\frac{1}{8}$ in. square at most; in those tissues having relatively large intercellular spaces considerably larger pieces may be employed.

As penetration takes place a deposition of indigo within the cell is effected, and at the same time the protoplasmic contents are fixed in the normal manner. After penetration is completely effected-the tissue should be cut in pieces of such a size that penetration is complete in $4^{-6}$ hours, or after twelve hours' immersion at most-the solution is poured off, and the material, after $3^{-4}$ washings of twenty-four hours each in $50 \%$ alcohol, is in a condition to be taken up through the alcohols to absolute alcohol in the usual manner.

As far as I am aware the only reference for the use of a persulphate in the formation of indigo in plant extracts or tissues occurs in a paper on the Fermentation of the Indigo Plant by Bergtheil (12). Here the author says: "The best method for precipitating indigotin from an extract of the plant is that devised by Rawson in I9OI for the analysis of indigoyielding plants. The extract is made strongly acid with hydrochloric acid, and a solution of ammonium persulphate is gradually added, the indigotin being precipitated in a finely crystalline form.' The method here stated to be devised by Rawson has not, as far as I can ascertain, been published by him. Its employment as here indicated, without modification, is not to be recommended, since with this combination a liberation of chlorine is 
effected which gives rise to a loss of indigo by oxidation. This loss is avoided by the use of sulphuric acid. Even now the proportion of persulphate to sulphuric acid is of considerable importance, since an excess of the former produces a further oxidation of indigo to isatin. Experiment has shown that in the above proportions a loss does not occur ${ }^{1}$.

The hardened material is now embedded in paraffin wax and ribbon sections cut in the normal manner. The thickness of the section depends, to a certain extent, upon the nature of the material. Thus, for Indigofera sp. a thickness of $4-5 \mu$ was found to be most suitable on account of the small size and dense arrangement of the cells. For Polygonum tinctorium the most suitable thickness is $8 \mu$; while for Isatis, Strobilanthes, Phajus, and Calanthe a thickness of $\mathrm{IO}-\mathrm{I} 2 \mu$ is advisable.

Staining. For this purpose a combination of Haematoxylin and Eosin was found most suitable. The sections, after successive immersion in xylol and absolute alcohol, are placed in a solution of Haematoxylin consisting of :-

$$
\begin{aligned}
& \text { Delafield's Haematoxylin • • • } 50 \text { c.c. } \\
& \text { Water . . . 3 } 300 \text { c.c. }
\end{aligned}
$$

in which they are left for at least twelve hours. They are then transferred to acid alcohol $(1 \% \mathrm{HCl}$ in $50 \%$ alcohol) until sections are almost colourless to the naked eye. After the removal of all traces of the acid and alcohol by washing in water, the sections are transferred to eosin- $\%$ solution of Gribler's water-soluble eosin-for at least an hour, after which they are rapidly dehydrated by absolute alcohol, passed into xylol and mounted in balsam. By this method a delicate differential coloration of cell-walls and cell contents is obtained in which the grains of indigo-blue stand out prominently and are hence readily localized.

\section{EXAMINATION OF MATERIAL.}

The material employed in the preliminary experiments was obtained from two species of Indigofera, I. sumatrana, Gaert., and $I$. arrecta, Hochst. These two species were made the subject of the most minute investigations, for the two reasons that they are the two indigo-yielding plants cultivated in Behar, where the work was commenced ${ }^{2}$, and that the indigo-yielding species of the genus Indigofera, being inhabitants of

1 In the 'Report to the Government of Bengal on the Research Work carried out at the Dalsing Sarai Research Station,' the above-described reagent is dealt with more fully from a macrochemical standpoint by W. P. Bloxam. This Report is, at the time of writing (Sept. 1904), still in the press.

${ }^{2}$ At the Dalsing Sarai Research Station. Here the plant was grown and the material prepared. Examination was deferred and finally carried out at the Botanical Laboratory, Cambridge. 
tropical climates, have received less attention than the corresponding species of various other genera which are either cultivated in temperate climates (Isatis and Polygonum) or are commonly met with under artificial conditions (Phajus and Calanthe). The various genera which have been subjected to investigation in the above-described manner will be considered separately.

\section{INDIGOFERA.}

Several species of this genus have been examined (loc. cit.) by Molisch, but the examination was-in the case of $I$. leptostachya $(=I$. arrecta) (13) and $I$. anil the only two species of those which he examined which yield indigo in any quantity-confined to dried material, and specimens of $I$. arrecta grown in the gardens at Prague.

According to his results (5), I. Dosua, I. argentea, I. chinensis, I. decora, $I$. hirsuta, and $I$. galegoides yield no indigo. The absence of an indigoyielding power in I. Dosua is also noted by Bréaudat (14).

In $I$. anil indigo can, according to Molisch, be precipitated in the leaves, especially in the mesophyll and epidermis, but not in the roots, stems, fruits, or seeds.

In $I$. arrecta he finds indigo precipitated as in $I$. anil, but on further examination of fresh material (7) this statement is amplified. He finds, by employing the 'alcohol-test' above described, the greatest amount of precipitation to have taken place in and on the chloroplasts of the chlorophyll bearing parenchyma of leaf-lamina. Very little occurs in the epidermal cells, with the exception of the epidermal hairs, in which larger amounts occur.

The following species have been examined recently after treatment with the Sulphuric-Acetic-Persulphate reagent:-
I. Dosua, Wall. Cat.
I. anil, L.
I. galegoides, D.C.
I. sumatrana, Gaert.
I. oligosperma, D.C.
I. arrecta, Hochst.

I. Dosua, Wall. Cat., growing in the Botanical Gardens, Cambridge, showed no trace of indigo.

I. galegoides, D.C. Material obtained from this plant growing in the Royal Botanic Garden, Calcutta, showed no trace of indigo after treatment.

I. oligosperma, D.C. Material from this plant was also obtained in the Royal Botanic Garden, Calcutta. The leaf only has been examined, and, when the chlorophyll had been removed by alcohol, appeared a distinct, though faint, blue colour. Microscopic examination of sections showed the distribution of indigo to be essentially the same as in $I$. arrecta described below. 
I. anil, L. This plant was also growing in the Royal Botanic Garden, Calcutta, where the material was obtained. Indigo was precipitated abundantly in the mesophyll of the lamina. In the remaining tissues of the leaflet only traces occurred; the distribution, however, is essentially the same as in $I$. arrecta, the difference is merely one of the degree of precipitation in the various tissues. The leaflets alone have been examined.

I. sumatrana, Gaert., and I. arrecta, Hochst. These two plants have been examined in greatest detail, and, since the distribution of the precipitated indigo is practically the same in both plants, they may be considered together.

Leaf-lamina. In the lamina of the leaflet of both species there is a marked palisade-parenchyma beneath the epidermis of the upper surface and a spongy parenchyma of small cells, compactly set, with small intercellular spaces. Between these two normal kinds of parenchymatous tissue, or isolating on the side of the palisade-parenchyma a few cells of the spongy parenchymatous type, occurs a layer, one cell in thickness, of large, irregular cells with a small amount of protoplasmic content and relatively few chloroplasts.

In all these varieties of parenchyma of the leaf-lamina indigo is precipitated, but it is especially abundant in the palisade-parenchyma, where it occurs as stellate masses either outlining a chloroplast, on the surface of which the indigo may be deposited, or suspended freely in the protoplasmic network of the cell (P1. XIII, Figs. I and 2). In the epidermis it also occurs abundantly, not only in the normal but in the two specialized types of epidermal cell-the guard-cells of the stomata and the epidermal hairs (Figs. 2-5). In the vascular bundles indigo is also abundant, and its distribution is best studied in the case of the midrib of the leaflet. Here the structure in no way departs from that of a normal leaf. The parenchymatous tissue, especially on the dorsal surface of the leaf, is composed of thick-walled cells with little or no chlorophyll. In the vascular bundles fibres are present to a very limited extent, the vessels being separated by thin-walled parenchymatous cells rich in protoplasmic contents.

In the xylem-parenchyma an abundant deposition of indigo is effected by the above-mentioned reagent. In the xylem-vessels alone is there no trace of deposition. Owing to the minute size of the elements of the phloem it is difficult to ascertain definitely where deposition actually takes place. A careful examination, however, shows that indigo may be present in all elements ; but the material is most unsuited for a clear demonstration (Fig. 6).

In the extra-vascular tissue of the midrib indigo is again present in abundance, more especially in the thick-walled dorsal parenchyma (Fig. 6).

The Rachis. The structure of the rachis differs from that of the mid- 
rib and approaches more nearly to that of the stem, in that the vascular strand has lost its dorso-ventral character and become completely circular, enclosing a central pith. There are two minor vascular strands situated in the two dorso-lateral ridges. Both the xylem and the cortex show a marked development of fibrous tissue which, in the latter case, forms a complete ring enclosing the central vascular strand. There are also numerous cells, situated both in the cortex and pith, which form an incomplete laticiferous system.

Considering the vascular cylinder first, we find indigo deposited in some quantity in the pith, except in the apparent laticiferous system where no trace occurs; it is also deposited in the cells forming the medullary rays. In the xylem it is completely absent from the vessels; traces alone occur in the fibres; while there is an abundant deposition in the xylemparenchyma. Indigo is present in all elements of the phloem. In all the cortical elements indigo is abundantly deposited, the above-mentioned cells of the laticiferous system alone forming an exception. Here no indigo is found. In the fibres there is a considerable deposition (Figs. 7, 8).

Stem. Indigo is only present in the young stem; as the distance from the growing point increases, the amount of indigo becomes progressively less and finally disappears. Deposition occurs in all the elements except, as before, in the xylem-vessels and laticiferous cells. For the first time a permanent cambium is found, in the cells of which indigo is deposited (Fig. 9). The phloem is bounded externally by a very definite and strongly developed fibrous layer, and outside this lies a well-defined endodermis. In the cells of both of these indigo occurs. Cortical fibres are not present, but the stem is strengthened by a considerable development of sclerenchyma at the angles opposite the primary bundles. In this sclerenchymatous tissue indigo is found deposited (Fig. Io). The epidermis, as before, contains blue deposited in the normal cells, guard-cells, and epidermal hairs.

Throughout the stem, however, the amount of blue deposited is relatively small. It is apparent to the naked eye, after the chlorophyll has been extracted with alcohol, as a faint though distinct blue colour which is very different to the deep blue of the rachis and leaflet. The abundant deposition in these latter ends abruptly at the swollen and somewhat prominent pulvinus.

Roots. There is no indication that the indigo-forming substance occurs in these.

Organs of Reproduction. The flowers of both species are small and only rendered conspicuous by the red colour of the two alae. The distribution of the indigo-forming substance varies slightly in the two species. In the calyx of $I$. sumatrana a considerable amount of deposition takes place, while, in all cases examined, that of $I$. arrecta showed a complete 
absence of blue. Of the corolla, the carina and vexillum show only the merest traces of blue deposition. No deposition could be traced in the alae of $I$. sumatrana; but in $I$. arrecta these contained a sufficient quantity to give a faint coloration, barely perceptible with the naked eye. In neither case did the filaments of the stamens show any trace of blue. The walls of the ovary up to, and shortly after, fertilization show a considerable deposition in the parenchymatous cells, as do the highly meristematic cells of the ovule of both species at the time of, and shortly after, fertilization. This applies to each of the component parts of the ovule, to the integuments, the nucellus, and even to the embryo-sac (Fig. II).

Shortly after fertilization all trace of blue vanishes from all parts of the ovary, nor does it appear in the ripe seed.

\section{ISATIS TINCTORIA, L.}

Owing to the fact that a temperate climate is best suited to the growth of this plant, it has supplied the material for some of the most detailed work which has so far been carried out, both on the subject at present under consideration and on the biological and fermentation problems connected with indigo and its formation from plant tissues.

Molisch in 1893 (5) used for a macrochemical investigation dilute ammonia. In localizing the blue-forming substance by alcohol vapour he finds traces in the roots, except those of flowering plants and of plants under fourteen days old, and in the cambium and epidermis of the stem. As regards the leaves he says: 'Schon die beiden im Lichte ergrüten Keimblätter und die jungen, die Plumula umhüllenden Primordialblätter enthalten sammt dem Vegetationspunkte des Stengels reichlich Indican.' He further locates the precipitated indigo in the epidermis, mesophyll, and those elements of the vascular bundles which have protoplasmic contents, especially the latter, so 'dass die ganze Nervatur als blaues Netz in Erscheinung tritt.' In the cotyledons it is present, while the flower-buds, but not the opened flower, contain a deposit of indigo.

In repeating the investigation in 1899 (8) he uses ammonia instead of alcohol-vapour. The position of the blue, as here described, differs somewhat from that previously allotted to it. The chlorophyll granules of the mesophyll stand out a deep blue. In the epidermal hairs and the epidermis, with the exception of the guard-cells and a few of the cells bordering on the guard-cells, only traces are present. The vascular bundles also show only traces.

Beijerinck, in I 900 (10), localizes indigo 'besides in the young leaves and buds, also in the young root-peridermis, in the root-buds and in the growing root-ends.' It is absent in the thick stems and all the thicker 
roots, the root-stock, the cambium and secondary tissues of woad-roots, flower-buds, embryo, seeds, and fruits.

Again, in I900 (15), by the action of boiling hydrochloric acid and ferric chloride on a thin section, indigo will be found deposited in the epidermal cells, and especially the hairs, of young leaves. It is also precipitated in the mesophyll and other parenchymatous tissues.

The sulphuric-acetic-persulphate reagent does not produce any large development of blue in Isatis, and it is consequently somewhat difficult to trace the locality of this deposition. In the epidermis precipitation occurs, especially in the guard-cells of the stomata. The main deposition occurs in the mesophyll and veins of the lamina, in which latter indigo occurs in all elements except the xylem-vessels. In the midrib there is only sufficient in the epidermis and extra-vascular parenchyma to give the faintest blue coloration. The merest traces occur in the parenchyma of the vascular strands of the midrib. The root-stock roots, flowering stalk, and organs of reproduction show no trace of blue after the above treatment.

\section{iII. Polygonum tinctorium, Ait.}

As in the case of Isatis tinctoria, the present knowledge chiefly depends on the work of Molisch. According to him (5) the indigo-forming substance can first be identified in the earliest foliage leaves, but not in the cotyledons; in these latter none is present, nor is there any in the root or hypocotyl of the young plant. In the fully-developed plant all parts, except the leaf-lamina, are, after treatment, colourless and devoid of indigo blue. The petioles and principal veins of the leaf, the stipules, stem, root, flower, and fruit are therefore devoid of the indigo-forming substance. In the epidermal cells of the lamina there is little, nor is there any abundance of indigo deposited in the parenchyma of the vascular bundles. In the mesophyll alone is it deposited in any quantity.

Beyond this little or no work has been undertaken on the localization in this plant. The examination made by Beijerinck in I900 (10) is only of a cursory nature, and his results, as far as they are stated, agree with those of Molisch as given above.

The present examination indicates that, as Molisch has shown, the leaf-lamina-especially of the young leaves-is the only locality where the dye-producing substance occurs. Beyond this, however, there is little agreement between the present results and those obtained by Molisch. The greatest deposition of indigo occurs in the epidermis, including both the guard-cells and the epidermal hairs. In the unspecialized epidermal cells deposition is so great that the plasma and nucleus are rarely distinguishable.

The mesophyll contains a considerable amount of indigo, and so 
do the vascular bundles, with the exception of the midrib. In the vascular bundles indigo is deposited in all elements except the xylem-vessels. In the older and fully-developed leaves the larger veins, in addition to the midrib, remain colourless on treatment.

\section{Phajus grandifolius, Lour.}

As early as 1830 this plant was recognized by Clamor Marquart to yield indigo (16). Reference has already been made to the work of Göppert and Müller-Thurgau (3 and 4), whose methods need not be recapitulated here. According to the former the localization in the flower is the same as in Calanthe: 'das Labellum der Blüthe und Operculum am dunkelsten, während die Pollenmassen, aber diese nur allein, ihre natürliche gelbliche Farbe ... behalten'; the flower, stalks, and bracts become blue, as do also the leaves. Müller-Thurgau only deals with the petals, the labellum in particular, in all of which he finds indigo deposited.

The distribution was next investigated by Molisch (5), precipitation of indigo being obtained by exposure to alcohol vapour. Briefly, he localizes indigo as follows :-

'Wurzel. Die relativ grösste Menge von Indican findet sich in den Meristemzellen der Spitze und in 1-3 Zelllagen knapp unterhalb der Wurzelhuille (Velamen). In den Wurzelhaaren, dem Velamen und dem übrigen Wurzelparenchym sehr wenig, nur Spuren in einzelnen Zellen des centralen Gefässbündelcylinders.

'Der Stengel und die knollenförmigen Verdickungen (Scheinknollen) desselben führen reichlich Indican.

'Blatt. In der Epidermis wenig, im grünen Parenchym viel, im Gefässbündel nur Spuren des Glykosids.

'Blüthe. Alle Theile, und zwar nahezu alle Zellen mit Ausnahme der Pollinarien indicanhaltig.'

Repeating his experiments in 1899 (8) he localizes the blue more particularly in the mesophyll, and especially the chloroplasts, of this tissue. The vascular bundles and epidermis, with the exception of the guard-cells, remain colourless to the eye, while the hairs, sieve-tubes, and raphide-cells contain no indigo.

Beijerinck, on the other hand, obtains blue depositions in the mesophyll and epidermis by boiling a section in hydrochloric acid and ferric chloride (10).

Only the aerial vegetative organs-the leaves and pseudo-bulbs-have been examined by the sulphuric-acetic-persulphate reagent. By this means the blue is deposited in the cell-plasm as very minute granules, the smaller of which are difficult to identify as such, even under the high powers of the microscope. 


\section{Substance in Indigo-yielding Plants.}

In both the young and old leaf an abundant deposition takes place in the parenchyma of the mesophyll, the xylem-parenchyma, and in the guardcells of the stomata (Fig. I2). In both the dorsal and ventral bundles of fibrous tissue embracing the vascular bundles less occurs, and the same may be said of the elements of the phloem; the epidermis, with the exception of the guard-cells already mentioned, contains only traces, while the xylem-vessels contain none (Fig. I3).

The pseudo-bulb contains a few vascular strands scattered throughout a parenchyma of unspecialized cells containing numerous starch-grains. Isolated in this parenchyma and scattered throughout it occur raphidecells. Indigo is deposited throughout the tissues of the pseudo-bulb excepting in the xylem-vessels and raphide-cells.

The amount of blue deposited in the vascular strands both of the leaf and pseudo-bulb is small compared with that in the mesophyll. As a result of this the vascular bundles appear to the naked eye as white strands embedded in a blue matrix.

\section{Phajus Wallichir, Lindl, and Phajus maculatus, Lindl.}

So far as I am aware, the only reference to these two species occurs in the article by Göppert on the freezing of plants (3). The aerial vegetative organs alone have been examined, and in all respects blue deposition is here similar to that in $P$. grandifolius.

\section{Calanthe.}

Calanthe was also first investigated by Göppert (3), and, as far as his investigation goes, the species of this genus investigated by him agrees in all respects with Phajus grandifolius.

Molisch (5), after an examination of both plants, states for Calanthe veratrifolia, Br.: 'Im Wesentlichen Alles so wie bei Phajus.'

This is the case, and it is therefore unnecessary to deal with the genus at length. Only two species have been examined-C. vestita, Lindl., and C. Veitchii, a cross between $C$. veratrifolia, Br., and $C$. rosea, Benth., in both of which species only the aerial vegetative organs have been subjected to the test.

Among other indigo-yielding plants which have been previously examined, but of which material has not been forthcoming for the present examination, are, Marsdenia tinctoria, $\mathrm{R}$. $\mathrm{Br}$. (5), Echites religiosa, $\mathrm{T}$. and $\mathrm{B}$. (17), Wrightia antidysenterica, R. Br. (17), and Crotalaria sp. (17).

\section{Strobilanthes flaccidifolius, Nees.}

This member of the Acanthaceae is largely cultivated in Assam for its indigo-yielding properties. A general account of it occurs in Watt's 
Dictionary of Economic Products (18). I can find no account of the localization of indigo in this plant, and on the present occasion opportunity has only offered for examining the stems and leaves of plants cultivated in Bengal. To the naked eye the deposition of indigo-blue produced by the sulphuric-acetic-persulphate reagent appears greater in the tissues of this plant than in those of any of the species previously considered.

Microscopic examination, after sectioning and staining, indicates that the blue is deposited in practically all tissues. The xylem-vessels alone are free from indigo. Traces indeed occur even here, but it is probable that, in a moderately succulent plant like the present, the mere cutting of the fresh tissue across the vascular bundles will transfer from the injured mesophyll-cells to the xylem-vessels a certain amount of cell-sap which, though small, will be sufficient to cause a deposition of blue in the latter. With this exception indigo may be said to be deposited in abundance in all tissues. The large, elongated cystolith-cells are especially prominent (Fig. 14) owing to the dense mass of blue deposited in them and around the cystolith. In the leaf the epidermal cells, including the guard-cells and the two forms of epidermal hairs (Fig. I5), the mesophyll, the collenchyma of midrib and lateral veins, the parenchyma of the vascular bundles and the sieve-tubes all contain indigo. In the stem the cortical collenchyma and the thin-walled chlorophyll containing parenchyma (Fig. I6), the xylem-parenchyma, the phloem-parenchyma, the few scattered fibres of the phloem and sieve-tubes and the pith similarly contain a deposit of indigo within the cell-plasm. The xylem-fibres, which form the greater bulk of the older stem, contain only traces, and the same may be said of the cambium (Fig. I7), which is not, however, very prominent. Here again, therefore, indigo is only absent from the xylem-vessels. No opportunity has yet occurred of examining the flowering stem and organs of reproduction.

\section{The Supposed Relation between the Chloroplast and the Indigo-producing Substance of the Plant.}

Molisch, after an examination of Phajus grandifolius, Calanthe veratrifolia, Isatis tinctoria, and Indigofera sp. concludes (8):-

'Erstens, dass die Chlorophyllkörner der Indicanpflanzen, wenn auch nicht den ausschliesslichen, so doch den Hauptsitz des Indicans darstellen, und zweitens, dass hiermit die Anwesenheit eines stickstoffhaltigen Glykosids im Chlorophyllkorn der genannten Pflanzen zum ersten Male nachgewiesen erscheint.'

The method already described for precipitating indigo within the tissue is used for the examination. An examination of the figures given by him are not convincing; moreover, Molisch himself shows that indigo 
occurs in certain cells where chloroplasts do not occur, e.g. the epidermal cells and vascular strands of Isatis (5); the blossoms of Echites religiosa (17); laticiferous vessels of Echites (17), \&c.

It is clear, therefore, that the indigo-forming substance is not located only in those cells in which chloroplasts occur; a fact which the foregoing account has made, if possible, more clear. The presence in tissues, other than those containing chloroplasts, does not of necessity preclude these bodies from taking an active part in the formation of the substance. The indigo-forming substance is undoubtedly a soluble body, and retained within the cell in a condition of solution. It may, therefore, pass from the chloroplast, where it is supposed to be formed, to the various tissues of the plant. It becomes necessary, therefore, before any part in the formation of the indigo-forming substance can be claimed for the chloroplast, to prove some definite relation between this and the blue precipitated. This can only be done by a minute examination of the distribution of indigo within a cell containing chloroplasts. For this purpose the cortical cells of a young stem of Strobilanthes is most suitable. Examination under a high power (Fig. I6) shows the blue distributed throughout the plasm of the cell. Here and there a granule may be found deposited in contact with a chloroplast, but in no case has it been possible to locate the blue within the latter body, as Molisch claims to have done.

Further, in no case where the deposition of indigo within the cells of a chlorophyll-bearing parenchyma has been examined has it been possible to trace deposition within the chloroplast. The indigo is, moreover, frequently found deposited in contact with the nucleus, and it seems impossible to lay greater stress on this contact in the one case than in the other. Until further proof, obtained from work along different lines, is obtained it is impossible to accredit to the chloroplasts any direct function in the production of the indigo-forming substance.

\section{LITERATURE。}

1. E. Schunck : Phil. Mag. (4), vol. x, p. 74, I 855 . On the formation of Indigo Blue, Part I.

2. $:$ Phil. Mag. (4), vol. xv, p. I 27,1858 . On the formation of Indigo Blue, Part II.

3. H. R. GöpperT : Bot. Zeit., 29, No. 24, p. 399, I87 I. Wann stirbt die durch Frost getödtete Pflanze, zur Zeit des Gefrierens oder im Moment des Aufthavens?

4. H. Müller-ThuRgau : Landw. Jahrb., ix, pp. 157-166, 1880. Ueber das Gefrieren und Erfrieren der Pflanzen.

5. H. Molisch : Sitzb. der Kais. Akad. d. Wiss. in Wien. Bd. cii, Abth. I, p. 269, I893. Das Vorkommen und der Nachweis des Indicans in der Pflanze, nebst Beobachtungen über ein neues Chromogen. 
6. H. Molisch : Zeitschr. des Allgem. Oesterr. Apoth.-Vereines. Bd. xlvii, p. 523, I893. Das Vorkommen und der Nachweis des Indicans in der Pflanze, nebst Beobachtungen über ein neues Chromogen. (Abstract of No. 5.)

7. $:$ Sitzb. der Kais. Akad. d. Wiss. in Wien. Bd. cviii, Abth. I, p. 479, 1899. Ueber Pseudoindican, ein neues Chromogen in den Cystolithenzellen von Acanthaceae.

8. - Berichte der Deutschen Botanischen Gesellschaft. Bd. xvii, p. 288, 1899. Ueber das Vorkommen von Indican im Chlorophyllkorn der Indigopflanzen.

9. M. W. Beijerinck : Proc. Roy. Academy of Sciences, Amsterdam. Bd. ii, p. 120, 1899. On the formation of Indigo from the Woad (Isatis tinctoria).

10. : Proc. Roy. Academy of Sciences, Amsterdam. Bd。 ii, p. 495, I900. On Indigo Fermentation.

11. J. J. Hazewinkel: Proc. Roy. Academy of Sciences, Amsterdam. Bd. ii, p. 512, I900. Indican-its hydrolysis and the enzyme causing the same.

12. C. J. Bergtheil : Chem. Soc. Journal, Trans., vol. lxxxv, p. 877 , 1904. The Fermentation of the Indigo Plant.

13. D. Prain and E. BAKER : Journal of Botany, vol. $x 1$, p. 143,1902 . Notes on Indigofera.

14. L. BRÉAUdAT : Comptes Rendus, 127, p. 769, 1898. Sur le mode de formation de l'indigo dans les procédés d'extraction industriels. Fonctions diastasiques des plantes indigofères.

15. M. W. Beijerinck : Proc. Roy. Academy of Sciences, Amsterdam. Bd. iii, p. IOI, I900. Further researches on the formation of Indigo from the Woad.

16. ROCHLEDER : Phytochemie, p. 224.

17. H. Molisch : Sitzb. der Kais. Akad. d. Wiss. in Wien. Bd. cvii, Abth. I, p. 747, 1898. Über die sogenannte Indigogährung und neue Indigopflanzen.

18. G. Watt : Dictionary of the Economic Products of India, vol. vi, pt. 3, S. 2930-2932. 


\section{$2 \mathrm{BHL}$ Biodiversity Heritage Library}

Leake, H. Martin. 1905. "The localization of the indigo-producing substance in indigo-yielding plants." Annals of botany 19, 297-310. https://doi.org/10.1093/oxfordjournals.aob.a089001.

View This Item Online: https://www.biodiversitylibrary.org/item/233541

DOI: https://doi.org/10.1093/oxfordjournals.aob.a089001

Permalink: https://www.biodiversitylibrary.org/partpdf/318799

\section{Holding Institution}

Smithsonian Libraries

\section{Sponsored by}

Biodiversity Heritage Library

\section{Copyright \& Reuse}

Copyright Status: Not in copyright. The BHL knows of no copyright restrictions on this item.

This document was created from content at the Biodiversity Heritage Library, the world's largest open access digital library for biodiversity literature and archives. Visit BHL at https://www.biodiversitylibrary.org. 